\title{
Menselijke kennis en rechtvaardiging: Eindige of oneindige ketens?
}

\author{
Harmen Ghijsen
}

ANTW 107 (2): 193-197

DOI: 10.5117/ANTW2015.2.GHIJ

In haar artikel bespreekt Jeanne Peijnenburg een van de belangrijkste controverses in de Angelsaksische epistemologie: het debat tussen fundamentisten en anti-fundamentisten. Volgens fundamentisten spelen zogenaamde basic beliefs een belangrijke rol in onze kennis en rechtvaardigingsstructuren: wanneer men blijft vragen naar de rechtvaardiging voor onze kennis, dan komt men uiteindelijk uit bij overtuigingen die gerechtvaardigd zijn zonder dat ze door verdere overtuigingen ondersteund hoeven te worden. ${ }^{1}$ Deze onafhankelijk gerechtvaardigde overtuigingen zijn wat fundamentisten basic beliefs noemen. Een belangrijke motivatie voor dit fundamentisme heeft te maken met het optreden van een oneindige regressie wanneer men het bestaan van basic beliefs op een bepaalde manier ontkent: als men volhoudt dat iedere gerechtvaardigde overtuiging op zijn beurt weer een nieuwe gerechtvaardigde overtuiging vereist om überhaupt gerechtvaardigd te kunnen zijn, dan leidt dit tot een oneindige keten van overtuigingen. En deze oneindige keten lijkt te impliceren dat geen enkele overtuiging in die keten gerechtvaardigd kan zijn. Immers, ieder onderdeel van de keten steunt op de rechtvaardiging van zijn voorganger, maar er is geen beginpunt dat onafhankelijk gerechtvaardigd is.

Dit is het punt waarop Peijnenburg het debat instapt. Volgens Peijnenburg is rechtvaardiging helemaal geen eigenschap die van overtuiging op overtuiging wordt overgedragen, maar een eigenschap die emergeert uit de volledige keten van overtuigingen. In dat geval hoeft er dus helemaal geen beginpunt te zijn van waaruit rechtvaardiging wordt doorgegeven en zijn

1 Ik ga er van uit dat de relatie tussen kennis en rechtvaardiging zodanig is dat kennis rechtvaardiging impliceert, maar rechtvaardiging niet kennis impliceert. Hoewel Peijnenburg dit niet expliciet beweert, lijkt zij hier ook mee akkoord te gaan. 
basic beliefs overbodig om het bestaan van rechtvaardiging te kunnen waarborgen. Om dit hard te kunnen maken is er wel een duidelijke beschrijving nodig van dit mechanisme van emergentie: hoe precies ontstaat rechtvaardiging geleidelijk uit een keten van elkaar ondersteunende overtuigingen? In haar artikel laat Peijnenburg zien dat we dit kunnen uitleggen door aan te nemen dat iedere overtuiging in de keten waarschijnlijk wordt gemaakt door zijn voorganger. Iets preciezer gezegd, q maakt $r$ waarschijnlijk als het volgende geldt:

$$
P(r \mid q)>P(r \mid \neg q)
$$

Volgens Peijnenburg kunnen we op deze manier over redenen en rechtvaardigingen nadenken, omdat een reden alleen een rechtvaardiging biedt voor een overtuiging als die de overtuiging ook waarschijnlijker maakt. ${ }^{2}$ Met deze aanname kan daarna worden aangetoond dat een oneindige keten van overtuigingen die ieder waarschijnlijk worden gemaakt door hun voorganger in de limiet leidt tot een eenduidige bepaling van de onconditionele waarschijnlijkheid van de te rechtvaardigen overtuiging. Als men nu aanneemt dat het hebben van een bepaalde onconditionele waarschijnlijkheid voldoende is voor het hebben van een gerechtvaardigde overtuiging, dan heeft Peijnenburg hiermee laten zien hoe rechtvaardiging kan emergeren uit een oneindige keten van elkaar ondersteunende overtuigingen. Bovendien blijkt dat de onconditionele waarschijnlijkheid van het beginpunt van de keten steeds minder belangrijk wordt in de bepaling van de onconditionele waarschijnlijkheid van het eindpunt van de keten naar mate deze keten langer wordt, een fenomeen dat Peijnenburg fading foundations noemt. Met andere woorden: zelfs in eindige ketens zijn basic beliefs zo belangrijk niet.

Met behulp van dit argument heeft Peijnenburg een belangrijk probleem voor anti-fundamentisten opgelost: oneindige ketens van overtuigingen zijn niet principieel incompatibel met het aanwezig zijn van rechtvaardiging, zo lang men maar op een specifieke manier over rechtvaardiging nadenkt. Echter, het is nog maar zeer de vraag of dit anti-fundamentisten de overhand geeft in het debat, laat staan dat is aangetoond dat basic beliefs geen principiële rol hebben te spelen in eindige ketens van overtui-

2 Merk op dat de precieze relatie tussen kennis, rechtvaardiging en waarschijnlijkheid niet zo duidelijk is, een te simpel beeld van deze noties leidt bijvoorbeeld tot de bekende lottery paradox. Bij een eerlijke loterij met veel loten is het voor ieder lot zeer waarschijnlijk dat het de loterij niet zal winnen, maar daaruit mag niet zomaar volgen dat men voor alle loten gerechtvaardigd is om te geloven dat (of nog erger: weet dat) het lot niet zal winnen. 
gingen. Dit heeft te maken met het onderscheid tussen propositionele en doxastische rechtvaardiging dat Peijnenburg aan het eind van haar artikel aanhaalt, maar helaas slechts kort bespreekt.

Waar propositionele rechtvaardiging te maken heeft met elkaar ondersteunende proposities, abstracte entiteiten die juist daardoor oneindig lange ketens kunnen vormen, heeft doxastische rechtvaardiging te maken met de vraag of een daadwerkelijke overtuiging echt gerechtvaardigd is, gegeven de wijze waarop men tot die overtuiging is gekomen. Om het verschil inzichtelijk te maken, kan men denken aan een moeilijke redenering die slechts door een enkeling kan worden uitgevoerd. Hoewel de beginpropositie in die redenering uiteindelijk via veel stappen tot de eindpropositie zal leiden, en de eindpropositie daarmee dan ook propositioneel gerechtvaardigd is, zullen velen nooit een overtuiging vormen met die eindpropositie als inhoud, en is er dus ook geen sprake van een doxastisch gerechtvaardigde overtuiging. En zelfs als iemand wel een overtuiging in de eindpropositie vormt op basis van de beginpropositie, dan nog betekent dit niet dat deze overtuiging daarmee doxastisch gerechtvaardigd is. Dit is alleen het geval als de persoon in kwestie ook via een goede redenering op die eindpropositie is uitgekomen. Wanneer we het dus willen hebben over wat rechtvaardiging of kennis nu eigenlijk voor ons mensen inhoudt; als we het, in Peijnenburgs woorden, willen hebben over 'de wijze waarop onze kennis is gestructureerd' (Peijnenburg 2015: 126, mijn cursivering), dan is doxastische rechtvaardiging de notie die prioriteit heeft.

Dit geeft een nieuwe draai aan het fundamentistische argument vanuit oneindige regressie, een versie die ook gepresenteerd wordt door bijvoorbeeld John Greco (2000). Hoewel een oneindige keten van elkaar ondersteunende overtuigingen in principe propositionele rechtvaardiging kan opleveren, zullen mensen in de praktijk geen oneindige ketens van elkaar ondersteunende overtuigingen gebruiken om tot een nieuwe overtuiging te komen. Sterker nog: aangezien onze cognitieve capaciteiten eindig zijn, lijken we niet eens in staat om oneindige ketens van elkaar ondersteunende overtuigingen te hebben! $!^{3}$ In dat geval moet de kennis en de daarbij behorende doxastische rechtvaardiging die we daadwerkelijk hebben dus toch los staan van oneindige ketens van overtuigingen en in plaats daarvan gestoeld zijn op bepaalde basic beliefs.

Een dergelijke opvatting sluit ook veel beter aan bij onze meest alle-

3 Merk op dat het toestaan van dispositionele overtuigingen misschien een oplossing voor dit laatste zou kunnen bieden; zie bijvoorbeeld (Audi 1994) voor meer over dispositionele overtuigingen. 
daagse voorbeelden van kennis. Denk bijvoorbeeld aan kennis op basis van wat we in onze omgeving waarnemen (perceptual knowledge), of kennis op basis van wat anderen ons vertellen (testimonial knowledge). In beide gevallen vormen we onze overtuigingen via een wel zeer korte keten: we geloven simpelweg wat we zien of wat ons verteld wordt zonder daarbij een heleboel andere overtuigingen in overweging te nemen. Natuurlijk is het zo dat, om kennis te kunnen vergaren, onze zintuigen wel correct moeten functioneren, en onze gesprekspartner wel de waarheid moet spreken, maar dit is iets waarmee de waarnemer of toehoorder normaal gesproken zelf geen rekening houdt. Sommige waarnemers, zoals kinderen of dieren, hebben niet eens de cognitieve vaardigheden om over dit soort zaken na te denken, terwijl ze wel het vermogen hebben om perceptuele kennis te vergaren.

Nadenken over hoe wij onze kennis daadwerkelijk vergaren lijkt dus tot een externalistisch fundamentisme te leiden, een fundamentisme volgens welke basic beliefs in eerste instantie gerechtvaardigd zijn op basis van betrouwbare processen van wie de betrouwbaarheid niet eens toegankelijk hoeft te zijn voor het subject van die basic beliefs. Een dergelijk fundamentisme is tegenwoordig een vrij populaire positie binnen de epistemologie en wordt uitvoerig verdedigd door bijvoorbeeld Jack Lyons (2009) en mijzelf (Ghijsen 2014). Merk op dat dit nieuwere fundamentisme niet zegt dat basic beliefs zeker moeten zijn, in tegenstelling tot bijvoorbeeld C.I. Lewis (1929) die door Peijnenburg als opponent wordt gebruikt. Voor de rechtvaardiging van basic beliefs is alleen nodig dat ze uit een betrouwbaar proces voortkomen, ze kunnen zelfs later weerlegd worden door nieuw bewijsmateriaal. Het moderne fundamentistische idee is eigenlijk zowel bescheiden als overtuigend: menselijke kenners moeten ergens beginnen in het vergaren van hun kennis, en basic beliefs vormen dit correcte beginpunt.

\section{Bibliografie}

Audi, R. (1994). Dispositional Beliefs and Dispositions to Believe. Noûs 28 (4), pp. 419-434.

Ghijsen, H. (2014). The Epistemic Puzzle of Perception. Conscious Experience, Higher-Order Beliefs, and Reliable Processes. PhD Thesis, URL: https://irias.kuleuven.be/handle/123456789/461866

Greco, John (200o). Putting Skeptics in Their Place: The Nature of Skeptical Arguments and Their Role in Philosophical Inquiry. Cambridge University Press.

Lewis, C.I. (1929). Mind and the World Order. An Outline of a Theory of Knowledge. New York: C. Scribner's Sons. 
Lyons, J.C. (2009). Perception and basic beliefs: Zombies, Modules, and the Problem of the External World. New York: Oxford University Press.

Peijnenburg, J., \& Atkinson, D. (2013). The Emergence of Justification. The Philosophical Quarterly, 63 (252), pp. 546-564.

Peijnenburg, J. (2015). Transmissie, Emergentie en Fading Foundations. Algemeen Nederlands Tijdschrift voor Wijsbegeerte.

\section{Over de auteur}

Harmen Ghijsen is een postdoctoraal onderzoeker aan de KU Leuven. Zijn onderzoek bevindt zich op het grensvlak van epistemologie en filosofie van de geest en hij heeft hierover gepubliceerd in toonaangevende internationale tijdschriften als Synthese en Erkenntnis. Op dit moment werkt hij met Springer aan een boek over de epistemologie van perceptie getiteld The Puzzle of Perceptual Justification. 
